\title{
Contemporary political ecologies of hydropower: insights from Bolivia and Brazil
}

\author{
Ed Atkins ${ }^{1}$ \\ Jessica Hope \\ University of Bristol, UK \\ University of St. Andrews, UK
}

\begin{abstract}
Twenty years after the World Commission on Dams published an oft-cited critique of hydroelectric projects across the globe, the energy infrastructure has experienced a renaissance. Dams, however, remain a highly contested energy source. In this article, we use two iterations of political ecology to challenge and complicate contemporary framings of hydropower as 'sustainable.' Focusing on political ecology's grounded, empirical reading of broader environmental and epistemological claims, we identify two different ways that insights from political ecology can reveal the contemporary relevance of the local scale in critiquing global hydropower infrastructure and its claims to be a part of global decarbonization agendas. Drawing from recent fieldwork in Bolivia and Brazil, we adopt frames of 'plurality' and the 'production of space' to analyze how local-scale dynamics of dam building challenge dominant definitions of sustainable hydropower. With the 'green-ness' of contemporary hydropower based on a narrow, $\mathrm{CO}_{2}$-centric definition, these insights complicate, challenge and broaden this definition by illuminating how the impacts of this energy infrastructure and power networks contradict claims of 'sustainability' and widen the relevance of respective projects' impacts, in terms of socionatures and ontologies. We argue that these hydropower projects limit the generative capacity of the local scale, in terms of place-based politics and socio-natures, and remake land- and waterscapes in the image of state and transnational extractive regimes. Together, our analysis opens up new trajectories for political ecology, to question the socio-environmental politics generated and enabled by the reworked environments of green energy production.
\end{abstract}

Keywords: Energy transitions, Hydropower, Brazil, Bolivia, extractivism, sustainability; political ecology; plurality; uneven development

\section{Résumé}

Vingt ans après que la Commission mondiale des barrages (WCD) a publié sa critique des barrages hydroélectriques à travers le monde, les barrages pour l'approvisionnement en énergie ont connu une renaissance. Les barrages restent cependant une source d'énergie très contestée. Dans cet article, nous utilisons deux itérations de l'écologie politique pour remettre en question et compliquer les cadres contemporains de l'hydroélectricité en tant que «durable». Nous développons une approche empirique fondée sur l'écologie politique, liée à des revendications environnementales et épistémologiques plus larges, afin d'identifier deux façons différentes d'utiliser la pertinence de l'échelle locale pour critiquer l'infrastructure hydroélectrique mondiale et ses prétentions à faire partie des programmes mondiaux de décarbonisation. Nous nous inspirons de récents travaux de terrain en Bolivie et au Brésil, en utilisant des arguments sur la «pluralité» et la «production d'espace» pour analyser comment la dynamique à l'échelle locale de la construction de barrages remet en question les définitions dominantes de «l'hydroélectricité durable». Les références environnementales de l'hydroélectricité reposent sur une définition étroite et centrée sur le CO2. Nos idées compliquent, remettent

\footnotetext{
${ }^{1}$ Dr. Ed Atkins is a Lecturer at the School of Geographical Sciences, University of Bristol, UK. Email: ed.atkins "at" bristol.ac.uk. Dr. Jessica Hope is a Lecturer in Sustainable Development at the School of Geography and Sustainable Development, University of St. Andrews, Scotland, UK. Email: jch31 "at" st-andrews.ac.uk. Acknowledgements: This research was supported by an ESRC Doctoral Studentship (Atkins, grant no: 1325180), RGS Environment and Sustainability Grant (Hope) and Vice-Chancellor's Research Fellowship at the University of Bristol (Hope). We extend our gratitude to the reviewers and Casey Walsh for their comments and assistance throughout this process.
} 
en question et élargissent cette définition en mettant en lumière la manière dont les impacts des barrages et des réseaux électriques contredisent les affirmations de «durabilité» et exposent la gamme des impacts, en termes de socio-natures et d'ontologies. Nous soutenons que les projets hydroélectriques refont les paysages terrestres et aquatiques à l'image de l'État et des régimes d'extraction transnationaux, modifiant la capacité générative de l'échelle locale, en termes de politiques et de sociocatures basées sur le lieu. Notre analyse ouvre de nouvelles trajectoires pour l'écologie politique, pour interroger les politiques socio-environnementales générées et permises par les environnements retravaillés de production d'énergie verte.

Mots clés: Transitions énergétiques, hydroélectricité, Brésil, Bolivie, extractivisme, durabilité; écologie politique; pluralité; développement inégal

\section{Resumen}

Veinte años después de que la Comisión Mundial de Represas publicara su crítica de los proyectos hidroeléctricos globales, la infrastructura energética ha experimentado un renacimiento. Las represas, sin embargo, siguen siendo consideradas como una fuente de energia muy debatida. En ese artículo, usamos dos tipos de ecología política para desafíar y complicar los encuadres contemporáneos que promueven la energía hidroeléctrica como 'sostenible'. Centrándonos en la lectura empírica y fundamentada de la ecologia politica sobre afirmaciones ambientales y epistemológicas, identificamos dos vias diferentes que las ideas ecología política puenden revelar la relevancia contemporanea de la escala local en criticar la infrastructura global hidroeléctrica y sus afirmaciones de formar parte de las agendas globales de descarbonización. Usando trabajo de campo reciente en Bolivia y Brazil, adoptamos marcos de 'pluralidad' y 'el producción de espacio' para analizar como las dinámicas de escala local en la construcción de la represas desafían el concepto dominante hidroelectricas sostenibles. La energia hidroelectrica es definida como "verde" basada en una vision centrada en $\mathrm{CO}_{2}$, sin embargo, nuestros resultados complican, desafían y amplian esta definicion, iluminando cómo los impactos de su infrastructura y redes eléctricas contradicen las afirmaciones de sostenibilidad y amplifican la relevancia de los impactos por ambos proyectos, en términos de las políticas basada en el lugar y las socionaturalezas. Proponemos que estos proyectos hidroeléctricos limitan la capacidad generativa a escala local (en términos de las políticas basada en el lugar y las socio-naturalezas) y rehacen paisajes acuáticos y terrestres según la imagen de regímenes extractivos estatales y transnacionales.Nuestro análisis abre nuevas trayectorias para la ecología política, para cuestionar las políticas socioambientales generadas y habilitadas por los entornos re-elaborados de la producción de energía verde.

Palabras clave: Transiciones energéticas, hidroeléctrica, Brasil, Bolivia, extractivismo, sostenibilidad; ecología política; pluralidad; desarrollo desigual

\section{Resumo}

Vinte anos depois da Comissão Mundial de Barragens ter publicado uma crítica frequentemente citada aos projetos hidrelétricos em todo o mundo, a infraestrutura de energia passou por um renascimento. Barragens, no entanto, continuam sendo uma fonte de energia altamente contestada. Neste artigo, usamos duas iterações da ecologia política para desafiar e complexificar os enquadramentos contemporâneos da energia hidrelétrica como 'sustentável'. Enfocando a leitura empírica e fundamentada da ecologia política de reivindicações ambientais e epistemológicas mais amplas, identificamos duas maneiras diferentes pelas quais as percepções da ecologia política podem revelar a relevância contemporânea da escala local na crítica da infraestrutura hidrelétrica global e suas reivindicações de fazer parte das agendas globais de descarbonização. Com base em pesquisas de campo recentes na Bolívia e no Brasil, adotamos quadros de 'pluralidade' e a 'produção do espaço' para analisar como a dinâmica da construção de barragens em escala local desafia as definições dominantes de energia hidrelétrica sustentável. Com a 'verdura' da energia hidrelétrica contemporânea com base em uma definição estreita e centrada no $\mathrm{CO}_{2}$, esses insights desafiam e ampliam essa definição, iluminando o modo como os impactos desta infraestrutura de energia e redes de energia contradizem as reivindicações de 'sustentabilidade' e ampliam a relevância dos impactos dos respectivos projetos, em termos de socionaturezas e ontologias. Argumentamos que esses projetos hidrelétricos limitam a capacidade de geração da escala local, em termos de políticas locais e socionaturezas, e refazem as paisagens terrestres e aquáticas à imagem de regimes extrativistas estatais e transnacionais. Juntas, nossa análise abre novos caminhos para a ecologia política, para questionar as políticas socioambientais geradas e possibilitadas pelos ambientes retrabalhados de produção de energia verde.

Descritores: Transições energéticas, energia hidrelétrica, Brasil, Bolívia, ecologia política, pluralidade, produção do espaço 


\section{Introduction}

In light of the 2015 Paris Agreement and the 17 Sustainable Development Goals (as set by the United Nations General Assembly), the energy landscape of the $21^{\text {st }}$ century is changing rapidly. Renewable energies - such as wind, solar and hydropower - are coming to represent significant proportions of energy matrixes across the globe. Although fossil fuels continue to dominate, the International Energy Agency (2018) has forecast that renewables will provide $12.4 \%$ of global energy demand by 2023 - an increase of $20 \%$ from 2017 . However, the 'sustainability' credentials of all renewable energy technologies are not certain and, it is important for scholarship to interrogate the political, social and spatial dimensions of these energy transitions (Bridge et al. 2013; Newell and Mulvaney 2013). Whilst a rise of solar, wind or hydropower may represent a break from the use of fossil fuels, it does not necessarily represent a departure from the episodes of power, exclusion and injustice that have characterized fossil fuel energy regimes (Bebbington and Bebbington 2011; Watts 2010) and may, instead, exacerbate or repeat these dynamics.

Whilst contemporary assertions of the 'sustainability' of hydropower may appear secure and consolidated in global policy, social scientists continue to interrogate the 'environmental' credentials of this energy source (Ahlers et al. 2015; Huber and Joshi 2015). Political ecology scholarship has done much to reveal the contested and contradictory effects of hydropower and its role within wider shifts to 'green' energy (Baird and Barney 2017; Blake and Barney 2018; Geheb and Suhardiman 2019; Martinez and Castillo 2016). In this article, we bring together two separate case studies on hydropower in the Amazon basin (namely, Chepete and Bala projects in Bolivia and the Belo Monte project in Brazil) and adopt elements of political ecology scholarship to navigate and critically interrogate the 'green-ness' of hydropower in the $21^{\text {st }}$ century. Focusing on political ecology's grounded, empirical reading of broader environmental and epistemological claims, we identify different ways that political ecology can reveal the local-scale relevance of global hydropower infrastructure and the claims its proponents make about a global energy transition. We reassert the need for the sustainability of an energy source to be traced back to the site of its generation and extraction, foregrounding contemporary energy transitions not only in the physical displacement of populations but also in the exclusion of these communities - both instrumentally (in terms of the distance between them and the site of consumption of the energy generated) and intrinsically (in terms of the marginalization of alternative worldviews, knowledges and claims to land and livelihoods). It is by illuminating these processes that we assert the continued importance of the local scale in understanding the apparent sustainability (or unsustainability) of contemporary hydropower.

The subsequent analysis is provided in five sections. In the next section, we detail the contemporary resurgence of hydropower and its characterization as a 'sustainable' energy source. In the third section, we adopt a political ecology lens to illuminate and interrogate the spatial and political dimensions of hydropower and the planning and construction of hydroelectric dams - before turning to our empirical case studies. In the first empirical section, we analyze the contested politics of the Chepete and Bala projects in Bolivia, questioning how these hinder an emergent politics of plurality. In the second empirical case, we explore how the Belo Monte project represents the occurrence of a Lefebvrian production of space, in which the Xingu river is (re)cast as a site of energy generation and the maldistribution of costs and benefits). In the final section, concluding remarks are made.

\section{The resurgence of hydropower}

Despite harsh criticism of large hydroelectric projects by the World Commission on Dams (2000), it is widely acknowledged that dam infrastructure experienced a resurgence in the first two decades of the $21^{\text {st }}$ century - with numerous states in the Global South turning to dam projects to address the twin challenges of energy insecurity and climate change mitigation (Moore et al. 2010; Dye 2019; Schulz and Adams 2019). Whilst the hydroelectric infrastructure of the 20th century was offered as a route for economic development, contemporary dam projects are often presented by their proponents as representing 'sustainable' energy that contributes to global goals related to climate change mitigation and sustainable energy transitions (Ahlers et al. 2015; Atkins 2018; Huber and Joshi 2015). The International Energy Agency (2018) has estimated that hydropower currently provides for approximately $16 \%$ of the world's total energy supply - with 32 countries, including Brazil, Mozambique and Norway - sourcing $80 \%$ of their electricity from hydropower. Although the 
expansion of hydropower has slowed - primarily due to a decline of these projects in China and Brazil - this global capacity is expected to increase, with new developments concentrated in Latin America and Sub-Saharan Africa (World Energy Council 2015). Over half of the world's river systems have been fragmented by the construction of over 45,000 large dams (Baghel and Nusser 2010; Nilsson et al. 2005). As of 2019, total global installed hydroelectric capacity equaled 1,307 gigawatts - and was projected to increase further (International Energy Agency 2019a).

Energy transitions are multi-scalar - with elements and episodes taking place at local, regional, national, and supra-national levels. Assertions of the assumed sustainability credentials of hydropower are primarily found at the national and international levels. National and global policies have positioned hydropower as a core element in sustainable energy transitions, due to its characterization as a renewable energy source (IHA 2019; UNFCCC 2018; World Bank 2009). This 'sustainability' is predicated in the assumed role of hydropower in leading to limited greenhouse gas emissions when compared to other dirtier energy sources (i.e. coal and oil). Hydropower projects are funded by the Clean Development Mechanism, a funding instrument, created by the 1997 Kyoto Protocol to channel funding from Annex I states (primarily in the Global North) to Annex II states (less economically developed, primarily in the Global South). As of February 2020, 2,181 hydropower projects had been provided with carbon credits under the CDM (CDM Pipeline 2020). With the CDM providing the primary conduit for global finance related to climate change mitigation measures, hydropower's position within it suggests a consolidated belief in this energy source as representing clean and green energy. Despite criticism linked to population displacement, social and environmental impacts, and greenhouse gas emissions (McCully 1996; Scudder 2005; WCD 2000), hydropower continues to be a primary part of numerous states' energy matrices. As Tracy Lane (2015), writing for the International Hydropower Association has argued:

There is broad consensus that, when properly planned and implemented, hydropower is an affordable, reliable, sustainable and modern technology. It can help communities, nations and regions to acquire a reliable supply of electricity, supporting economic and social development throughout the world.

We - and numerous anti-dam movements - dispute this consensus and argue for more attention to contemporary local-scale impacts, to both illuminate and interrogate the divergent experiences and consequences of energy transitions. Whilst efforts made towards reducing and mitigating project impacts (see Schulz and Adams 2019) and improving best practice (see Hydropower Sustainability Assessment Protocol), dam construction continues to impact individuals and communities that are often neglected by both policymakers and pro-dam actors (Martínez and Castillo 2016). The flow of the river is diverted and/or restricted by a project's construction, disrupting the livelihood strategies of local communities, transforming socio-cultural relationships with the waterscape and creating new tensions surrounding access to resources. A large dam leads to population displacement and relocation, resulting in the movement of large portions of the local population into new areas, often geographically distant from their previous homes (Duflo and Pande 2007; McCully 1996; WCD 2000).

An important difference between the dam projects of the past and those in the modern era is found in the funding of projects. Whilst dams in the $20^{\text {th }}$ century were primarily funded by centralized, state actors, recent years have witnessed the arrival of international finance into the hydropower sector - with traditional funders (such as the World Bank) taking on a more backseat, faciliatory role (Ahlers and Merme 2016; Ahlers et al. 2017; Merme et al. 2014). The significant increase in transnational, private funding for hydropower raises questions about accountability, transparency, and equity in $21^{\text {st }}$ century dam's construction. Whilst private actors gain from short-term returns, it is often local communities who face the long-term impacts of projectconstruction (Ahlers et al. 2017; Ahlers and Merme 2016; Carmona and Puerta Silva 2020). The Nam-Theun 2 project in Laos PDR is a case in point, financed by 27 parties, including national financial institutions and investment funds (Merme et al. 2014). Many of the funders of hydropower projects in Laos PDR are commercial banks based in neighboring Thailand, which are in turn linked to private international funds and banks (Middleton 2009). With scholars previously discussing the role of 'green' infrastructure in creating new areas 
of capitalist activity and providing a socio-ecological fix in times of capital crisis (Castree and Christophers 2015; McCarthy 2015; Smith 2007), hydroelectric projects have come to represent sites for the absorption of surplus capital in the $21^{\text {st }}$ century (Ahlers 2020). Whilst local communities and ecologies are irreversibly dislocated, 'sustainable' hydropower has been accompanied by speculation, profit and 'accumulation by dispossession' (Duarte-Abadia et al. 2015).

The transformation caused by a hydroelectric project is not only biophysical and material but involves the institutional reordering of a river basin and the communities living on its banks (Ahlers et al. 2017; Ahlers 2020). The historical construction of water supply infrastructure has represented the urban-centric ambitions and imaginaries of increased water supply, enrolling rural areas into the networks of pipes and reservoirs to providing growing cities with water (Hommes and Boelens 2018). This, in turn, creates new spatial relations between rural and urban areas, with a river transformed in the name of putting it to 'productive' use (Hommes and Boelens 2018). In the case of the Sogamoso dam project in Colombia, the construction of a hydroelectric project (built in the name of clean energy and sustainable development), broke up the previous agreements and practices that underpinned water users, use and rights, creating a new set of hierarchies of use in the watershed (Duarte-Abadia et al. 2015). The compensation programs enacted to mitigate social impacts of a dam cast a long shadow with the processes of valuation and abstraction that form them resulting in the commodification and enclosure of resources, such as commonly-held land (Nathan Green and Baird 2016). Despite assertions of the 'sustainability' of hydropower, the development of this infrastructure can come to represent the reproduction of patterns of power inequity, with energy supply becoming inscribed with the wider forms of injustice and structural power (Harrison 2016; Manorom et al. 2017; Martínez and Castillo 2016).

\section{The political ecologies of energy transition}

As the planning and construction of hydroelectric projects has enjoyed a global resurgence, so have the social movements that stand against them (Del Bene et al. 2018). We understand the debates surrounding hydropower in the $21^{\text {st }}$ century as representing the contestation over different approaches to, and definitions of, sustainability, with pro and anti-dam coalitions debating what should be sustained, the routes available to achieve this and who it should be sustained for (Adger et al. 2003; Leach, Scoones and Stirling 2010; Sikor and Norgaard 1999). 'Sustainability' narratives exclude alternative voices by depoliticizing a project, characterized as a process in which a certain policy or phenomena is raised above the realm of contentious politics (Swyngedouw 2010; Turhana and Gündoğan 2018; Wilson and Swyngedouw 2014). The contemporary depoliticization of 'sustainable' hydropower is predicated a 'carbon fetishism' that both commodifies greenhouse gas emissions and elevates them as the primary metric of a sustainable future (Swyngedouw 2010). In terms of energy transitions, this fetishization of $\mathrm{CO}_{2}$ as a metric for success elevates the gas to a position that determines the environmentalist, sustainability or 'environmental credentials' of an energy source (such as hydropower), neglecting wider and cumulative impacts, such as environmental degradation or political and economic marginalization.

In this article, we use political ecology in two different iterations to explore the problematic 'greening' of hydropower. In discussing "the relations between the social and the natural, arguing that social and environmental conditions are deeply and inextricably linked" (Adams and Hutton 2007: 149), a political ecology lens necessitates paying attention to the politics that co-constitute natures. For example, exploring how relationships of power or the difference between how groups encounter and treat their biophysical environments (Guha and Martínez Alier 2013; Neumann 2006; Robbins 2011; Peet and Watts 2004). It means identifying the politics behind environmental policies, projects, practices and agendas, as well as trying to better understand how politics shapes ecological outcomes (Adams and Hutton 2007; Lawhon and Murphy 2011; Peet and Watts 2004). Here, we first foreground how political ecologies emerge in post-colonial contexts. Political ecology has long been committed to empirically grounded research and, in doing so, has critically engaged with how natures, knowledge and expertise are created and justified in postcolonial contexts (Sundberg 2014). However, recent and intensifying demands for decolonisation (see Mignolo and Walsh 2018), require political ecology to go further in attending to decolonial agendas. Decolonial praxis is growing as a response to modernity/coloniality, evading neat theorization (Mignolo et al. 2018) to promote multiple ways of knowing, living and world-making in attempts to reverse colonial histories, hierarchies and knowledges (Tuck et al. 2012). In Latin America, 
amongst other demands, decolonising movements have called for Indigenous territorial sovereignty, the decolonisation of Nature, and a recognition of the plural ways of knowing and being (see Anthias 2018; Escobar 2018).

Here, we combine Huber's (2015) assertion that energy production is uniquely generative of politics, with decolonising agendas for territory and plurality in Latin America (de la Cadena and Blaser 2018; Halvorsen 2018). Scholarship on the 'pluriverse' draws on Zapatista thinking to promote (and create) a "world where many worlds fit" (Escobar 2018: xvi) and to reposition cultural and political autonomy as central (Escobar 2018: ix$\mathrm{x}$ ). This confronts colonial histories but also reveals the potential political implications of doing so, for example for supporting alternative ways of valuing nature(s) as a way to challenge the hegemony of extractive logics (Cadena and Blaser 2018). Calls to decolonize knowledge, however, recognize knowledge as "deeply imbricated in power" (Noxolo 2017) and as tied the political, material, and structural contexts of knowledge production (ibid). Decolonizing knowledge therefore involves a radical restructuring of the ownership and use of resources and land (Esson et al. 2017; Tuck and Yang 2012). Engaging with these concepts of decoloniality also necessitates more engagement and clarity on the positionality of those researchers in the Global North (us) engaging with and writing about decolonial agendas. Here, we take seriously Indigenous territorial agendas and plurality to advance a critique of the consequences of hydropower projects and dams. We explore this importance of plurality in the case of the Chepete and Bala project in Bolivia, drawing from qualitative data collection conducted by Hope from 2012 and with Indigenous territorial movements, NGOs and state ministries, primarily undertaking semi-structured interviews, participant observation and participatory mapping.

Second, we center analysis of the contestation of hydropower upon the recognition of the role that power relations and asymmetries play in determining access to (and the use of) water and energy resources. Energy infrastructure - of all kinds - provides a central mechanism through which society's relationship with the environment, and with other people, is mediated (Huber 2015; Larkin 2013). As a result, a transition to a different energy regime is simultaneously a political and a spatial process - producing and reproducing networks of interaction between people, landscape and energy (Bridge et al. 2013; Calvert 2015; Huber 2015; Rutherford and Coutard 2014). These built environments facilitate the extraction of a certain utility or value from natural systems to fulfil the energy demands of the wider population. Energy relations are viewed as constitutive of power and politics more broadly, be it in shaping urban infrastructures or through consumptive practices, and new energy systems are examined for the "new spatialities and new spatial imaginations" that they engender (Huber 2015: 1).

Political interests, ideologies, competition, and strategies are also powerful influences in defining what a renewable energy policy looks like - influencing what technologies are adopted, where they are located and who benefits from the energy generated. In doing so, renewable energy transitions develop "new geographies of winners and losers", with the costs and benefits inequitably spread across the locality, region or state (Bridge et al. 2013: 337). We explore the vital importance of the production of new spatialities and geographies in the case of the Belo Monte project in Brazil. In this section, we adopt the concept of production of space to explore the ways in which the material ordering brought by hydropower is manifested in localized impacts but also in the relationship between energy-production and transmission. In Section 5 - based on data collection via semistructured interviews in Brazil in 2016 and 2017 (Atkins) - we highlight the transformation of the region around the Belo Monte site to illuminate the ways in which it, and its communities, face a material reordering at the behest of energy users and interests elsewhere.

\section{The importance of plurality in the Chepete and Bala dams}

In this section, we adopt the concept of plurality (and its related politics) to consider how hydropower projects encounter and rework bids for radical, progressive and transformative political change - locating hydropower megaprojects in a wider framework of extractivism. Political ecology scholarship has often identified and analysed the problematic impacts that extractivism has on territories, conservation areas and Indigenous and collective rights (Bebbington 2008; Hindery 2004; Humphreys Bebbington 2010, 2013; Kaup 2009; Perreault 2008, 2013; Perreault and Valdivia 2010). This has involved work on how extractivism has 
curtailed progressive agendas as well as how it is entangled with claims for recognition, identity, sovereignty, democracy and citizenship (Arsel et al. 2016; Pellegrini 2018).

Although there is not the scope here to cover the wide-ranging and fertile discussions and debates surrounding postcolonialism and, more recently, decolonization in depth, it is important to assert that they seek to challenge the constitutive legacies of colonial exclusion and division and set out to "decentre, diversify and decolonize the narratives that have come to over-represent and legitimize continued forms of colonization, erasure, and violence" (Jackson 2017: 6). In doing so, calls to recognise plurality advocate for working towards both the recognition and nourishment of difference as a way to support subaltern communities to strengthen their autonomy and enact, consolidate and secure their own respective lifeworlds (Escobar 2018). These ideas are often examined as political ontology, which foregrounds diverse ways of knowing and understanding the world (see Holbraad and Pedersen 2017; Joronen and Häkli 2017). This is relevant to critiquing hydropower as 'sustainable' energy as this frame goes beyond contested claims to land, to recognize and include the different knowledges and practices of nature, society and development that are challenged and threatened by the construction of hydropower projects in a region.

Bolivia is a particularly relevant national context in which to use the frame of plurality. State commitments to 'pluri-nationalism', as set out in the 2009 Constitution, refer to a process for "territorial resignification and demographic occupation of state territory by multiple social movements" (Mamani 2011) and to Indigenous territorial rights, citizenship, and natural resources (Gustafson 2002; Radcliffe 2012). Plurinationalism here seeks ways to decolonize approaches to social, political, and environmental life and enable cultural and political autonomy for diverse groups (and their diverse ways of knowing and being). Under President Morales (2005-2019), this involved agendas for decolonization (and state ministers), as well as attempts to incorporate Indigenous ontologies of development and nature into the guiding principles of the state (for more see Canessa 2014; Zimmerer 2015). This is, in part, linked to discourses of Vivir Bien, roughly translated as 'Good Life' or 'Good Living.' Conceptualized by contemporary Indigenous scholars, Vivir Bien has been articulated in response to hegemonic logics and practices of development. Buen Vivir is disseminated as an idea from below that has its roots in Indigenous cosmovisions, socio-natures and ontologies (Gudynas 2016) and marks a critical response to classical Western development theory and more recent bids for sustainable development, as it decentres growth and moves toward a more holistic measure of wellbeing (Gudynas 2011; Radcliffe 2012; Walsh 2011).

The simultaneous development of energy and extractive infrastructure in Bolivia, however, has revealed the contradictions and challenges facing progressive, plural and decolonial agendas. Commitments to hydrocarbon extraction, as well as other forms of mining, were promoted and justified by the Morales government under the umbrella of 'progressive extractivism', which links extractive projects to increased welfare benefits for the poorest members of Bolivian society (Gudynas 2013: 25). In 2006, the Morales government re-nationalized the hydrocarbons industry through contract renegotiations with global firms. Bolivia secured a higher percentage of royalties from private gas companies (amounting to US\$5.5 billion in 2014 and US\$3.7 billion in 2015) (Kaup 2010; Fabricant and Gustafson 2016: 273) but continued to work closely with transnational firms - relied upon to for their expertise and technologies (Kaup 2010: Fabricant and Gustafson 2016). The socio-environmental impacts of neo-extractivism are significant, as new extractive projects cross into Indigenous territories, conservation areas and reconfigure agricultural landscapes (Radhuber et al. 2021). Commitments to resource extraction in Bolivia have mirrored an unprecedented rise in resource extraction across Latin America, since the resource boom of the early 2000s. This has been exploited by neoliberal and post-neoliberal states (Bebbington and Humphreys Bebbington 2011), which have pursued an 'extractive imperative' in Latin America (Arsel et al. 2016), whereby progressive agendas are being appropriated and reworked to fit within the broader developmentalist, extractive regime.

It is in this context that new hydropower projects are under construction in Bolivia's lowland region. Chepete and Bala are two neighbouring hydropower plants, under construction in the Department of La Paz, Bolivia. They will be built on the River Beni, an Amazon tributary that runs through Bolivia's Western Amazon Basin. Bala, to the North, will be the smaller of the two dams and will flood an area of $94 \mathrm{~km}^{2}$. Chepete, downstream of Bala will flood $677 \mathrm{~km}^{2}$ (Fundación Solón 2019). The Chepete and Bala projects were an important part of the plans of President Morales to transform Bolivia into a regional energy hub - exporting 
hydroelectricity to neighbouring countries, such as Brazil. The projects - estimated to generate 3.676 megawatts of electricity, which will likely be sold to Brazil - are part of an ambitious government plan to develop 35 hydroelectric projects across Bolivia by 2025 (La Razón Digital 2016).

The River Beni forms the perimeter of both the Madidi National Park and the Pilon Lajas TCO (Indigenous territory) and, subsequently, the construction of Chepete and Bala dams involve ceding land from both a conservation area and an Indigenous territory. The government estimates that these hydropower plants will affect just $0.7 \%$ of Madidi and $1.2 \%$ of Pilon Lajas and the dams are promoted by the government as "the most important works in the history of Bolivia" and are planned with the strictest regard for the environment (Juárez 2016). However, anti-dam activists have contested the socio-environmental impacts of the projects including the displacement of 5,000 people, the disruption of patterns of land use and livelihoods (particularly related to ecotourism industries in the region) and significant environmental impacts, including disruption to habitats. ${ }^{2}$ Such impacts are not only linked to the Chepete and Bala sites but also stem from the road infrastructure required for the construction of, and access to, these dams.

The construction of the necessary transport infrastructure (in a country with ambitious plans to extend road and transport networks) will likely bring new claims on land in Madidi National Park, one of Bolivia's most important national parks. Valued by Bolivian environmentalists and global conservation organizations alike, this park forms an important part of Bolivia's Vilcabamba-Amboró Corridor, thought to contain the most significant levels of biodiversity in Bolivia (USAID 2008). In addition to the direct environmental impacts of the dams, opposition actors highlight how the development of road infrastructure will likely lead to increased rates of deforestation in the area (Bebbington et al. 2018). Opposition actors have drawn attention to the effects of dam construction on high biodiversity in the Vilcabamba-Amboró Corridor, and on cumulative impacts that not only directly impact the immediate locality but that will have far-wider importance - impacting forest cover in the Western Amazon region that is vital for fighting global climate changes (Finer et al. 2015). This supports research that has looked more widely at the environmental impact of energy infrastructure and found that roads bring new forms of access to previously inaccessible areas, and new claims for land and deforestation (Bebbington and Humphreys Bebbington 2018).

The frame of plurality reveals that the process of constructing the dam also limits the possibilities for bottom-up and diverse forms of territorial development, politics, and well-being. As set out in state commitments to international law ILO 169 and within the 2009 Constitution, the Pilon Lajas territory should have been consulted over the project plans, to ensure free, prior, and informed consent (FPIC). However, no such efforts were made by the proponents of the projects until after the environmental impact assessments had been completed and the plans for the project fully formulated (Achtenberg 2017). Previous work has demonstrated that in contemporary Bolivia, those opposing extractivism, (particularly environmentalists) face increasing restrictions and criminalization (Andreucci and Radhuber 2017; Hope 2016, 2020). Far from embracing a pluralistic understanding of difference and political autonomy, it is evident that governmental actors instead sought to restrict and shut down opposition to the Chepete and Bala projects. For example, in December 2016, then Vice-President of Bolivia Alvaro García Linera, publicly stated that the government would not listen to the grievances of those opposing the projects, dismissing anti-dam actors as saboteurs, funded by foreign interests to "impede Bolivia's development and foment water shortages" (Achtenberg 2017). This dismissal - and demonization of oppositional actors - represents an important parallel with the Belo Monte dam project in Brazil, where pro-dam actors have frequently accused activists of being involved in an 'international conspiracy' to delegitimise and restrict opposition action (Atkins 2017; Zhouri 2010). Anti-dam activists become cast as subversive, treacherous, and criminal - with their grievances and demands cast aside, rather than being heard in consultations based around their right to FPIC.

This process of criminalization is further evident in the treatment of other anti-dam actors, those outside of the Pilon Lajas territory. Pablo Solón Romero, for example, was previously the Bolivian Ambassador to the United Nations (UN) (2009-2011) and is now director of the non-governmental organization (NGO), Fundaccion Solon. He has publicly opposed the Chepete and Bala project, criticizing the social and environmental impacts of the dams and supporting local activists in Pilon Lajas (Fundación Solón 2017). On

\footnotetext{
${ }^{2}$ As revealed in research interviews.
} 
30 June 2017, Solón was served a subpoena for corruption - linked to the allegation that he usurped Morales' executive power by presenting the journalist Rafael Archondo as his successor as UN ambassador. In response, Solón released a public statement, stating:

The news wasn't a surprise. Due to our critical analysis of the El Bala and El Chepete hydroelectric megadams, various friends had warned me that they would search underneath the stones to find something to accuse me of, to intimidate me, and to make me shut up. (Fundación Solón 2018)

Although Solón was subsequently released and the charges dropped, these claims of intimidation are echoed in wider findings and concerns about contemporary social movement politics in Bolivia (Andreucci and Radhuber 2017; CEDIB 2014). Whilst Morales presented himself as an anti-capitalist politician, advocating for Indigenous rights and Vivir Bien, his critics argued that his administration was increasingly characterized by extractivism and the marginalization of alternative voices (CEDIB 2014; Hope 2016; Perreault 2013; Svampa 2015).

When considering how different energy sources prompt changes to political life, Chepete and Bala are interesting due to the ways they echo the contested politics of extractivism. Despite being sites of contemporary 'sustainable' energy, Chepete and Bala should be viewed as extensions of the extractive project - rather than as part of a wider transition of energy sources within Bolivia. The process and politics of realising these projects echo the other energy initiatives that fulfil the government's bid to be the energy heart of Latin America complimenting contemporary hydrocarbon exploration, rather than signalling its demise. In terms of how the dams encounter and rework bids for plurinationalism and territorial autonomy, analysis of the Chepete and Bala dams have highlighted the limited autonomy of Pilon Lajas, in terms of the restriction of FPIC and their right to decide what happens within the borders of the territory, as well as impacting upon their economic activities. The dams will be detrimental to livelihoods within the territory, which predominantly stem from eco-tourism itself a strategy for sustainable development. Those opposing the Chepete and Bala dams were clear that

It is a discourse of living well but the one that the government proposes is not - theirs is a discourse of hydroelectricity, mining, extraction, hydrocarbons... (Berta)

Whilst the concept has been widely promoted as post-development and an alternative to development (Escobar 2005; Walsh 2010), government interpretations came to characterise Vivir Bien as incorporating redistributive policies (such as income transfers) into industrial growth and infrastructure construction (Bell 2017). As a result, anti-extractive territorial movements struggle to engage with Vivir Bien (Hope 2020).

The two central conclusions taken from this analysis are first, that these hydropower megaprojects are undermining Indigenous territorial rights. Such rights to land and governance have been demanded over years, as Indigenous nations have experienced, challenged and negotiated colonial rule, its continuities and its legacies. This includes overriding existing strategies that marry development and the environment, such as eco-tourism projects and livelihoods. This offers an important critique of new hydropower projects, revealing the significance of the geography and location of hydropower projects, as they repeat and entrench post-colonial injustice and exclusion. Second, theories of plurality, and linked decolonising agendas, reveal these territories as potentially generative of new political projects, hybrid socio-natures and place-based ways of knowing and treating the non-human (see Escobar 2018; Sundberg 2014; de la Cadena 2018; Mignolo and Walsh 2018). From the perspective of plurality, the hydropower projects in Chepete and Bala thus risk limiting and curtailing alternative avenues for socio-environmental transformation, wellbeing, and sustainability.

\section{Belo Monte and the production of space}

The second frame of political ecology that we wish to advance to interrogate hydropower's role as 'green' energy foregrounds attention to the production of space. We adopt this term to refer to how physical infrastructure - such as a hydroelectric dam - can provide a primary conduit for powerful actors to enroll 
landscapes into wider patterns of economic development or energy politics. Following Neumann (2010), we understand regions abundant with hydroelectric potential - that are deemed hydroelectric frontiers or akin to batteries to be drawn on for energy - as heavily entwined with the transformation of nature and related power asymmetries. They provide an intermediary, through which state power not only interacts and alters nature-state relations but also transforms localized experience. Vulnerable communities exist along the supply chain of energy production and consumption, with sites of injustice present from the generation of electricity to its enduse (Hernández 2015). Costs and benefits are unevenly distributed spatially (Duarte-Abadia et al. 2015) and certain areas and regions of energy production are 'sacrificed' for what is deemed to be in the best interests of meeting the state's energy needs. These 'energy sacrifice zones' house nuclear, coal, liquified natural gas (LNG) or hydropower energy infrastructure and often have a disproportionate impact on low-income communities or communities of color (Hernández 2015). Such a politics of uneven development is structural, rather than an accidental byproduct of economic growth and change (Smith 1984; 1986). As a result, it is necessary to foreground an analysis of energy projects - such as hydropower - within a wider study of the role that regional dynamics and relationships play in the social production and reproduction of space, as well as in the extraction of value from one region to serve another.

When examining the construction of a dam, it is important to interrogate the multi-scalar links between the everyday, localized impacts of hydropower construction, and national policies that enable - and drive forward - their construction, as well as international interests that are financially involved (Ahlers 2020). The adoption of the work of Henri Lefebvre (1991) allows for the development of an understanding of the planning and construction of hydroelectric dams are representative of not just a material, biophysical change in the river basin but also as the site of a prolonged and dynamic struggle over what the river is, how it can be used, and wider policies (Ahlers et al. 2017). Lefebvre's three dimensions of space provide a particularly fruitful route to understanding the ways in which the planning, construction and impacts of a hydroelectric dam re(produce)s these land- and waterscapes (see Ahlers 2020). The first element is 'perceived' space, which can be found in terms of the physical, material construction of a project and its biophysical impacts. The second element is 'conceived' space, which functions in the discourses and framings that are adopted to both legitimize and challenge construction. The third element is 'lived', namely the ways in which the new energy landscape, and its impacts, are experienced. The construction of a dam alters the socio-economic, physical-ecological, and politico-cultural characteristics of the region in which they are located. The flow of the river is diverted and/or restricted by a dam project's construction. This disrupts local common property resources, altering the livelihood strategies of local communities and transforming socio-cultural relationships with the waterscape. The river is reconfigured, with a new regime of interaction imposed and the dam functioning to enroll it into a new pattern of interaction that remakes 'perceived', 'conceived' and 'lived' space in the image of, in this case, state energy policy and global capital.

To explore this role of the transformation of space and uneven development in contemporary hydropower, we turn to the case of the Belo Monte project in Brazil. This project is an 11,233 MW dam, completed in 2019, built on the Xingu River in Pará state in the Brazilian Legal Amazon Region. The planning and construction of the project has extended over thirty years, and it was subject to extensive opposition from local groups (representing Indigenous, rural, and urban communities), as well as from national and international organizations. The project (built according to a run-of-the-river design) involves the diversion of $80 \%$ of Xingu's flow through a set of human-made channels to power 24 turbines, generating electricity to be distributed across Brazil.

With the Brazilian energy system organized around a national grid, it is not rare for energy to be produced in one region and used in another. The geographical location of population centres and clusters is often different from the regions with the highest potential for energy generation, be it in terms of wind, solar or hydropower necessitating such transmission. The $21^{\text {st }}$ century has witnessed an increased clustering of hydroelectric projects - serving households and industries in other federal states - in the Brazilian Amazon. The Amazon basin is home to $63 \%$ of Brazil's total hydroelectric potential (Soito and Freitas 2011) and over 100 hydroelectric dams. As of 2016, a further 79 were planned or under construction in the basin (Lees et al. 2016).

The Brazilian Amazon region has a long history of encroachment and enrollment of the basin - and its communities - into the wider economic policies, aspirations, and imaginaries of powerful actors in Brazil. For 
example, within the development policies of the military junta that ruled Brazil between 1964 and 1985, this region has provided the arena within which the dominance of a particular social group and vision of economic progress has been exercised in the control and the transformation of space. This territoriality from 'above' is often statist and technocratic, focused on notions of development or conservation and has taken multiple forms: from telegraph poles to modern carbon sinks, from gazetted forest reserves to roads and highways - all part of the same project, the rendering of the Amazon landscape legible and as part of the Brazilian national political landscape (see Balletti 2012).

A key site of this remaking of Amazonia by the Brazilian military junta was the town of Altamira, Pará - which is found on the route of the Rodovia Transamazonica. This corner of the Brazilian Amazon - and the rural landscapes formed of forest, Indigenous communities and other non-Indigenous, traditional communities of the Xingu river (such as river-dwellers and artisan miners) has experienced the entrance of numerous development projects devised and managed by distant actors (see Bratman 2020). Whilst the city of Altamira is a regional economic center, the municipal district of Altamira is characterized by a low population density, with 0.62 persons per $\mathrm{km}^{2}$ (IBGE nd.). Stretching to $160 \mathrm{~km}^{2}, 96 \%$ of the district is an environmental conservation area. For many of those living in the region, the construction of the Belo Monte represented the next stage of state-intervention into the region, with development projects symbolic of the enrolling of this pocket of Amazonia into state development schemes. For others, this was the first such episode that they had experienced. For everybody, Altamira and the surrounding region were to undergo a process of restructuring both internally (in terms of everyday life and experience) and in more-institutional terms, with Altamira's role as an urban center becoming restructured, affirmed and broadened (Miranda Neto and Herrera 2016), both in terms of the regional economy and national energy politics.

The Belo Monte project was part of a developmentalist policy agenda pursued by the Partido dos Trabalhadores (Workers' Party, PT) governments of Presidents Luiz Inácio Lula da Silva (2003-2011) and Dilma Rousseff (2011-2016). Central within these plans is the increase in hydropower generation - to provide cheap energy to provide a baseline for future energy matrices (i.e. acting as a battery to shore-up the national grid in terms of shortages). This provision of energy security was a particularly important element in justifying the project (Atkins 2017). At the turn of the millennia, Brazil experienced an energy shortage that resulted in nine months of electricity rationing (between June 2001 and March 2002) and saw a reduction of 16.3\% in average energy use (Carvalho 2006). This represented one of the most dramatic energy crises faced by modern Brazil, resulting in extensive energy rationing, rolling blackouts and a ghost of energy insecurity that continues in rhetoric today. As Atkins (2017) has explored elsewhere, these two notions provided a primary route for justifying the Belo Monte project for its supporters - with the dam coming to promise a brighter future for all, both in the immediate region and beyond. When justifying the Belo Monte project, numerous supporters argued that the project was necessary to ensure the electricity supply necessary for continued economic growth and the related increase in living standards, whilst ensuring sustainable development (Atkins 2017; 2019). However, these assertions have been challenged by the material reordering, concentrated in the area around the project's construction, in terms of both Lefebvre's 'perceived' space (altered in terms of the project's biophysical impacts on river flow and land inundation) and 'lived space' (the disruption caused to the day to day lives of the local population).

This transformation of space is particularly evident in the city of Altamira, the popular center closest to Belo Monte's construction site. The population of Altamira in 2010, when Belo Monte's construction began, was 99,075 (IBGE nd.). It then increased dramatically. Hydroelectric projects both require and mobilize an extensive labor force - with both construction workers and those in subsidiary sectors arriving at new construction sites, towns, and regions. A local anti-dam network, Xingu Vivo para Sempre (2010) estimated that, when taking both those in direct or indirect employment into account, the construction of Belo Monte led to an influx of 100,000 workers and new residents.

Whilst the environmental license provided to Belo Monte contained numerous conditions linked to the mitigation of the project's social impacts on the population of Altamira - including the construction of new schools and health clinics and sanitation systems, these conditions were widely presented by anti-dam actors as having failed (ISA 2015; Southgate 2016). The strain put upon local infrastructure led to the utter transformation of Altamira, the center of this population influx. Food and commodity prices increased (Atkins 2020) and crime 
spiked (Southgate 2016). Altamira experienced a rapid escalation in violent crime - experiencing 124 murders per 100,000 inhabitants in 2015 (an increase of 147\% from 2009, when the Belo Monte project was approved), leading to it becoming the deadliest city in the world (Madeiro 2017). Sexual violence increased by $18.5 \%$ (MAB 2013) and police raids illuminated a network of trafficked sex work, set up to cater to the new residents of Altamira (Glass 2013; Talento 2014). Altamira was irreversibly transformed, with its population displaced, bloated, and dislocated. Violent crime has remained - as evident in a 2019 prison riot between rival drug trafficking gangs that led to 58 deaths (Aroeira 2019). The buildings in which it took place were overcrowded - with the Altamira prison system waiting for the construction of a new space by Norte Energia, as per a condition in Belo Monte's construction license.

Outside Altamira, riverine communities were dislocated and dispersed - with the homes built to rehouse those displaced being distant from the river and other members of the community. These communities were often underpaid for their land (Álvares 2019) and relocated with little regard for their distinctive culture (guaranteed in Brazilian law). The fishing communities that remained downstream experienced declining catches, forcing them to travel further to catch less (Castro-Diaz 2018). The region's Indigenous communities faced extensive flux and change - with the mitigative measures designed to support them, in the face of Belo Monte, leading to livelihood change and cultural loss. The Plano Emergencial (Emergency Plan), run by Norte Energia between 2010 and 2012, paid R $\$ 30,000$ (US\$9,000) in financial support and goods to Indigenous villages in the region every month. The Caciques of each village would submit a list of goods that the community required, which were subsequently provided. New houses were built and electricity generators, vehicles and boats provided. However, these mitigative measures created extensive disruption - for example, switching from diets of cassava and fresh produce to processed foods. Fields were no longer planted, alcohol abuse increased - as did diabetes, hypertension, and drug use (Brum 2015a; 2015b; Instituto Socioambiental 2015). Livelihoods were disrupted and Indigenous communities and culture fragmented - leading Thai Santi, a federal prosecutor based in the region, to describe the Plano Emergencial as leading to a holocaust and ethnocide (Brum 2014).

This represents the alteration of socio-ecological relations that is the focus of political ecology scholarship, including recent studies of dam impacts. Whilst the communities nearest Belo Monte experienced a profound change to their everyday lives, the energy generated by the scheme (a benefit of the project) was transmitted across Brazil via two extensive transmission lines into the national grid. The first will channel the electricity 2,100 kilometers south to the Estreito substation in the state of Minas Gerais - from where it will be distributed to the population centers in the southeast of Brazil (BMTE nd.). The second transmission line will stretch 2,500 kilometers south, directly to the city of Rio de Janeiro on the Atlantic coast (Teixeira and Costa 2015). ${ }^{3}$

Whilst the above demonstrates the externalities of Belo Monte leading to the transformation of space and communities' relationship to it, the Belo Monte case provides an important example of how the material reordering brought by a hydroelectric project can result in the entrance of new actors, new opportunities for extraction and disruption, and further alteration of the region itself. In Brazil, the expansion of hydropower is often coupled with the escalation of extractive industries (Barrow 1988; Fearnside 2016). The state of Pará, where Belo Monte is located, is the state with the largest extractive potential (being home to deposits of gold, iron ore and bauxite, among other minerals) and provided a focal point for investment. The Belo Sun mining project in the area of riverbed exposed by the Belo Monte project, is set to become the largest open-pit gold mine in the country. The project, led by a Canadian mining company, is predicted to cover a 620 square mile area $\left(1,606 \mathrm{~km}^{2}\right)$. With Belo Monte nearing completion, Belo Sun produces an additional set of impacts that are intimately linked to the construction of the dam, including high levels of energy and water demand (Movimento

\footnotetext{
${ }^{3}$ Both projects have been tendered to the Chinese state-owned power company, State Grid. Both these lines have had extensive environmental impacts. The first transmission line runs close to 10 separate conservation areas and likely resulted in the clearance of 1,725 hectares of native vegetation in both the Amazon and the Cerrado savannah (Leal 2016). This is infrastructure that - running the length of Brazil - enrolls new spaces and communities into the national energy grid that underpins Brazilian energy politics. The lines highlight the requirement for research to explore the connections between hydropower and the production of space to draw attention to the intricate relations between energy production and transmission.
} 
dos Atingidos por Barragens 2017; Poirier 2017; Sullivan 2017). The development of the Belo Sun site has been linked to episodes of violence and intimidation of local communities, heightened tensions related to contested land tenure and increased water pollution (MPF/PA 2017; MAB 2015).

The case of Belo Monte demonstrates that the construction of a hydroelectric dam remakes space in a number of ways - both in terms of everyday experience (i.e. population influxes, insecurity and violence) but also in terms of the enrollment of land and waterscapes (and the energy resources contained within) into wider patterns of economic development, energy relations and extractions. As with geographies of fossil fuel extraction and 'sacrifice zones', the building of a hydroelectric dam is intricately tied to the construction of particular regions as 'batteries' to provide energy to population centers and emergent arenas of extraction, into which new actors enter. This, in turn, alters and recalibrates spatial patterns of development, exclusion and difference within the region - leading to population influxes, increased violence and the disruption of the cultural and everyday lives of those living there. The Belo Monte dam - localized in its siting and impacts - is located with an extensive network of actors and processes. The interactions between these actors, the watercourse and local communities all occur at the behest of national strategies of energy security or economic development and constituted by the demands for energy. As a result, it comes to represent a key site in Brazil of where rural and urban landscapes become interrelated - with the disruption of one providing benefits for the other.

The result is a produced energy landscape that is spatially uneven, with the costs (social and environmental impacts) and benefits (the provision of energy) not equitably shared. The construction, generation, and transmission of hydroelectricity at Belo Monte resulted in impacts that were externalized onto local communities living near the site of construction. Whilst it is the population of south-east Brazil that enjoys and benefits from the renewable, green energy produced at the Volta Grande of the Xingu River, it is the populations of Altamira and the surrounding region who bear the costs, in the form of social and environmental impacts. As a result, the space around Belo Monte (i.e. the Xingu river, Altamira and other towns and villages, and the lives of the population) are all recast and dislocated. The Xingu's flow is altered, disrupting river morphology and fish migratory routes ('physical' space'), homes are lost and insecurity dominates ('everyday' space) and the project comes to represent a site of disconnection between the national level discourse of 'green' energy and the extensive impacts experienced by those in living near the site of construction ('conceived' space).

\section{Concluding remarks}

Across contemporary Sustainable Development and environmental policy agendas, the necessity to move away from fossil fuels - and their externalities - is clear and widely subscribed to. The twinned goals of climate change mitigation and meeting increasing energy demand have resulted in many states investing in renewable energy infrastructures, such as solar wind, geothermal and hydropower. Yet despite previous criticism of its social and environmental impacts, hydropower is widely presented in policy circles as having a significant role in this transition to 'green' energy. The social and ecological impacts of a hydroelectric project, however, are not solely a question of energy security, production or consumption but are, instead, representative of wider processes related to the organization of space, political economy and contested claims of socio-natural relations.

In this article, we have interrogated how the construction of hydroelectric dams results in the exacerbation of pre-existing spatial and political tensions between state institutions, individuals, and communities. We have outlined two avenues in which political ecology scholarship is able to engage with, critique and interrogate contemporary transitions to 'sustainable' energy sources - and the role of hydropower within such a transition. First, we have combined theories of plurality with Huber's (2015) assertion that energy production is uniquely generative of politics, to question how the Chepete and Bala dams encounter and rework bids for transformative socio-environmental politics. We have argued that these hydropower megaprojects are undermining Indigenous territorial rights, overriding existing trajectories for socio-environmental wellbeing and sustainability and limiting possibilities for transformation. Second, we have drawn from Lefebvre's theory of the production of space to understand the ways in which the planning, construction and impacts of a hydroelectric dam (re)produces these land- and waterscapes (see Ahlers 2020). We have argued that the Belo 
Monte case demonstrates that the construction of a hydroelectric dam remakes space in a number of ways both in terms of everyday experience (i.e. population influxes, insecurity and violence) but also in terms of the enrollment of land and waterscapes (and the energy resources contained within) into wider patterns of economic development, energy relations and extractions.

Taken together, we argue for the contemporary relevance of the local scale as generative of political projects, development trajectories and new socio-natures. Hydropower projects limit the generative capacity of the local scale, in terms of place-based politics and socio-natures, as well as remaking land and waterscapes in the image of state and transnational capital. This leaves us questioning what socio-environmental politics and forms of future-making will be prompted and enabled by these reworked environments of green energy production.

\section{References}

Achtenberg, E. 2017. The growing resistance to megadams in Bolivia. NACLA.org, 14 February. [accessed April 25 2019]. https://nacla.org/blog/2017/02/20/growing-resistance-megadams-bolivia

Adams, W.M. and J. Hutton. 2007. People, parks and poverty: political ecology and biodiversity conservation. Conservation and Society 5(2): 147-183.

Adger, W.N., T.A. Benjaminsen, K. Brown and H. Svarstad. 2003. Advancing a political ecology of global environmental discourses. Development and Change 32(4): 681-715.

Ahlers, R. 2020. Where the walls of power meet the wall of money: hydropower in the age of financialization. Sustainable Development 28: 405-412.

Ahlers, R., J. Budds, D. Joshi, V. Merme, and M. Zwarteveen. 2015. Framing hydropower as green energy: assessing drivers, risks and tensions in the Eastern Himalayas. Earth System Dynamics 6(1): 195-204.

Ahlers, R. and V. Merme. 2017. Financialisation, water governance and uneven development. WIRES Water 3: 766-774.

Ahlers, R., M. Zwarteveen and K. Bakker. 2017. Large dam development: from Trojan Horse to Pandora's Box. In B. Flyvbjerg (ed.) The Oxford handbook of megaproject management. Oxford: Oxford University Press.

Álvares, D. 2019. Belo Monte, a violação de direitos humanos dos ribeirinhos e a ameaça ao Xingu. The Huffington Post Brasil, 4 September. [accessed: 8 January 2020]. https://www.huffpostbrasil.com/entry/belo-monte-altamira_br_5d6efef4e4b09bbc9ef644fd

Andreucci, D. and I.M. Radhuber. 2017. Limits to "counter-neoliberal" reform: mining expansion and the marginalisation of post-extractivist forces in Evo Morales's Bolivia. Geoforum 84: 280-291.

Anthias, P. 2018. Limits to decolonization: Indigeneity, territory, and hydrocarbon politics in the Bolivian Chaco. Ithaca: Cornell University Press.

Aroeira, A. 2019. Belo Monte forjou o massacre de altamira: novo presídio nunca entregue era obrigação da norte energia. The Intercept Brasil, 7 August. [accessed: May 28 2020]. https://theintercept.com/2019/08/06/belo-monte-forjou-massacre-altamira/

Arsel, M., B. Hogenboom and L. Pellegrini. 2016. The extractive imperative in Latin America. The Extractive Industries and Society 3(4): 880-887.

Atkins, E. 2017. Dammed and diversionary: the multi-dimensional framing of Brazil's Belo Monte dam. Singapore Journal of Tropical Geography 38(3): 276-292.

Atkins, E. 2018. Dams, political framing and sustainability as an empty signifier: the case of Belo Monte. Area 50(2): 232-239.

Atkins, E. 2019. Disputing the 'national interest': the depoliticization and repoliticization of the Belo Monte Dam, Brazil. Water 11(1): 103.

Atkins, E. 2020. Contesting the greening of hydropower. Political Geography 80: 102179. 
Baird, I.G. and K. Barney. 2017. The political ecology of cross-sectoral cumulative impacts: modern landscapes, large hydropower dams and industrial tree plantations in Laos and Cambodia. The Journal of Peasant Studies 44(4): 769-795.

Baghel, R .and M. Nüsser, M. 2010. Discussing large dams in Asia after the World Commission on Dams: is a political ecology approach the way forward? Water Alternatives 3(2): 231-248.

Baletti, B. 2012. Ordenamento Territorial: neo-developmentalism and the struggle for territory in the lower Brazilian Amazon. The Journal of Peasant Studies 39(2): 573-598.

Barrow, C. 1988. The impact of hydroelectric development on the Amazonian environment: with particular reference to the Tucurui project. Journal of Biogeography 15(1): 67-78.

Bebbington, A.J. 2008. The new extraction: rewriting the political ecology of the Andes? NACLA Report on the Americas 42(5): 12-20.

Bebbington, A.J. and D. Humphreys Bebbington. 2011. An Andean avatar: Post-neoliberal and neoliberal strategies for securing the unobtainable. New Political Economy 16(1): 131-145.

Bebbington, A.J. and D. Humphreys Bebbington. 2018. Mining, movements and sustainable development: concepts for a framework. Sustainable Development 26: 441-449.

Bebbington, A.J., D. Humphreys Bebbington, L.A. Sauls, J. Rogan, S. Agrawal, C. Gamboa, A. Imhof, K. Johnson, H. Rosa, A. Royo and T. Toumbourou. 2018. Resource extraction and infrastructure threaten forest cover and community rights. Proceedings of the National Academy of Sciences 115(52): 1316413173.

Bell, K. 2017. 'Living well' as a path to social, ecological and economic sustainability. Urban Planning 2(4): 19-33.

Blake, D.J.H. and K. Barney. 2018. Structural injustice, slow violence? the political ecology of a "best practice" hydropower dam in Lao PDR. Journal of Contemporary Asia 48(5): 808-834.

Belo Monte Transmissora de Energia (BMTE). n.d. A empresa. BMTE. [accessed April 252019 ]. http://www.bmte.com.br/the-company/

Bratman, E.Z. 2020. Governing the rainforest: sustainable development politics in the Brazilian Amazon. Oxford: Oxford University Press.

Bridge G., S. Bouzarovski, M. Bradshaw and N. Eyre. 2013. Geographies of energy transition: space, place and the low-carbon economy. Energy Policy 53: 331-340.

Brum, E. 2014. Belo Monte: a anatomia de um etnocídio. El Pais, 1 December. [accessed 30 March 2020]. https://brasil.elpais.com/brasil/2014/12/01/opinion/1417437633_930086.html

Brum, E. 2015a. Belo Monte, empreiteiras e espelhinhos. El Pais, July 7. [accessed April 252019 ]. https://brasil.elpais.com/brasil/2015/07/06/opinion/1436195768_857181.html

Brum, E. 2015b. O dia em que a casa foi expulsa de casa. El Pais, September 14. [accessed April 25 2019]. https://brasil.elpais.com/brasil/2015/09/14/opinion/1442235958_647873.html

Brum, E. 2016. Dilma compôs seu réquiem em Belo Monte. El Pais, May 10. [accessed April 252019 ]. https://brasil.elpais.com/brasil/2016/05/09/opinion/1462804348_582272.html

Cadena M. de la and M. Blaser (eds.). 2018. A world of many worlds. Durham: Duke University Press.

Calvert, K. 2015. From 'energy geography' to 'energy geographies': perspectives on a fertile academic borderland. Progress in Human Geography 40(1): 105-125.

Canessa, A. 2014. Conflict, claim and contradiction in the new 'indigenous' state of Bolivia. Critique of Anthropology 34(2): 153-173.

Carmona, S. and C. Puerta Silva. 2020. How do environmental impact assessments fail to prevent social conflict? Government technologies in a dam project in Colombia. Journal of Political Ecology 27: 10721091.

Carvalho, G. 2006. Environmental resistance and the politics of energy development. The Journal of Environment \& Development 15(1): 245-268. 
Castree, N. and B. Christophers. 2015. Banking spatially on the future: capital switching, infrastructure and the ecological fix. The Annals of the American Association of Geographers 105(2): 378-386.

Castro-Diaz, L., M.C. Lopez, and E. Moran. 2018. Gender-differentiated impacts of the Belo Monte hydroelectric dam on downstream fishers in the Brazilian Amazon. Human Ecology 46(3): 411-422.

Centro de Documentación e Información Bolivia (CEDIB). 2014. Extractivismo: nuevos contextos de dominacion y resistencias." La Paz, Bolivia: CEDIB. [accessed April 25 2019]. https://cedib.org/publicaciones/extractivismos-nuevos-contextos-de-dominacion-y-resistencias/

CDM Pipeline (2020) CDM Pipeline, UNEP DTU Partnership. [accessed: February 14, 2020]. http://www.cdmpipeline.org/cdm-projects-type.htm\#3

Puerta Silva, C., B. Duarte-Abadía, B., R. Boelens and T. Roa- Avendaño. 2015. Hydropower, encroachment and the re-patterning of hydrosocial territory: the case of Hidrosogamoso in Colombia. Human Organization 74(3): 243-254.

Duflo, E. and R. Pande. 2007. Dams. The Quarterly Journal of Economics 122(2): 601-646.

Escobar, A. 2005. Encountering development: The making and unmaking of the Third World. Princeton: Princeton University Press.

Escobar, A. 2018. Designs for the pluriverse: radical interdependence, autonomy, and the making of worlds. Durham: Duke University Press.

Esson, J., P. Noxolo, R. Baxter, P. Daley, and M. Byron. 2017. The 2017 RGS-IBG Chair's theme: Decolonising geographical knowledges, or reproducing coloniality? Area 49: 384-388.

Fabricant, N. and B. Gustafson. 2016. Revolutionary extraction? Mapping the political economy of gas, soy, and mineral production in Evo Morales's Bolivia. NACLA Report on the Americas 48(3): 271-279.

Fearnside, P.M. 2016. Environmental and social impacts of hydroelectric dams in Brazilian Amazonia: implications for the aluminum industry. World Development 77: 48-65.

Finer, M., B. Babbit, S. Novoa, F. Ferrarese, S.E. Pappalardo, M. De Marchi, M. Saucedo and A. Kumar. 2015. Future of oil and gas development in the western Amazon. Environmental Research Letters 10(2): 24003

Fundación Solón. 2017. Aunque nos metan a la cárcel El Bala y el Chepete son inviables. Fundación Solón, July 3. [accessed May 28 2019]. https://fundacionsolon.org/2017/07/03/aunque-nos-metan-a-la-carcelel-bala-y-el-chepete-son-inviables-2/

Fundación Solón. 2018. Fiscal rechaza denuncia contra Rafael Archondo y Pablo Solón. Fundación Solón, March 2. [accessed May 28 2019]. https://fundacionsolon.org/2018/03/02/fiscal-rechaza-denunciacontra-rafael-archondo-y-pablo-solon/

Fundación Solón. 2019. Impactos en la naturaleza de El Bala, Chepete, Rositas y Cachuela Esperanza. Fundación Solón, March 1. [accessed May 28 2019]. https://fundacionsolon.org/2019/03/01/impactosen-la-naturaleza-de-el-bala-chepete-rositas-y-cachuela-esperanza/

Geheb, K. and D. Suhardiman. 2019. The political ecology of hydropower in the Mekong River Basin. Current Opinion in Environmental Sustainability 37: 8-13.

Glass, V. 2013. Adolescente é resgatada de prostíbulo em Belo Monte. Reporter Brasil, 14 February. [Accessed: March 19 2019]. https://reporterbrasil.org.br/2013/02/adolescente-e-resgatada-de-prostibulo-em-belomonte/

Gudynas, E. 2011. Buen Vivir: today's tomorrow. Development 54(4): 441-447.

Gudynas, E. 2013. Debates on development and its alternatives in Latin America: a brief heterodox guide. In Lang, M. and D. Mokrani (eds.) Beyond development: alternative visions from Latin America. Quito: Fundacion Rosa Luxemburg. Pp. 15-39.

Gudynas, E. 2016. Beyond varieties of development: disputes and alternatives. Third World Quarterly 37(4): 721-732.

Guha, R. and J. Martínez Alier. 2013. Varieties of environmentalism: essays north and south. London: Routledge. 
Gustafson, B. 2002. Paradoxes of liberal Indigenism: Indigenous movements, state processes, and intercultural reform in Bolivia. In Maybury-Lewis, D. (ed.). The politics of ethnicity: indigenous peoples in Latin American states. Cambridge: Harvard University Press.

Halvorsen, S. 2019. Decolonising territory: dialogues with Latin American knowledges and grassroots strategies. Progress in Human Geography 43: 790-814.

Harrison, C. 2016. Race, space, and electric power: Jim Crow and the 1934 North Carolina rural electrification survey. Annals of the American Association of Geographers 106(4): 909-931.

Hernández, D. 2015. Sacrifice along the energy continuum: a call for energy justice. Environmental Justice 8(4): 151-156.

Hindery, D. 2004. Social and environmental impacts of World Bank/IMF-funded economic restructuring in Bolivia: an analysis of Enron and Shell's hydrocarbons project. Singapore Journal of Tropical Geography 25(3): 281-303.

Holbraad, M. and M.A. Pedersen. 2017. The ontological turn: an anthropological exposition. Cambridge: Cambridge University Press.

Hommes, L., and R. Boelens. 2018. From natural flow to 'working river': Hydropower development, modernity and socio-territorial transformation in Lima's Rímac watershed. Journal of Historical Geography 62: 8595.

Hope, J. 2016. Losing ground? Extractive-led development versus environmentalism in the Isiboro Secure Indigenous Territory and National Park (TIPNIS), Bolivia. Extractive Industries and Society 3(4): 922929.

Hope, J. 2020. Globalising Sustainable Development: decolonial disruptions and environmental justice in Bolivia. Area. (early view)

Huber. M. 2015. Energy and social power: from political ecology to the ecology of politics. In Perreault, T., G. Bridge and J. McCarthy (eds.). The Routledge handbook of political ecology. London: Routledge.

Huber, A. and D. Joshi. 2015. Hydropower, anti-politics, and the opening of new political spaces in the Eastern Himalayas. World Development 76: 13-25.

Humphreys Bebbington, D. 2010. The political ecology of natural gas extraction in Southern Bolivia. PhD dissertation. University of Manchester.

Humphreys Bebbington, D. 2013. Extraction, inequality and indigenous peoples: insights from Bolivia. Environmental Science and Policy 33: 438-446.

Humphreys Bebbington, D. and A.J. Bebbington. 2010. Extraction, territory, and inequalities: gas in the Bolivian Chaco. Canadian Journal of Development Studies / Revue canadienne d'études du développement 30(1-2): 259-280.

Instituto Brasileiro de Geografia e Estatistica (nd.) [IBGE]. Altamira - Panorama [accessed May 28 2020]. https://cidades.ibge.gov.br/brasil/pa/altamira/panorama

Instituto Socioambiental. 2015. Dossiê Belo Monte: não há condições para a Licença de Operação. Brasilia, D.F. [accessed May 28 2020].

https://documentacao.socioambiental.org/noticias/anexo_noticia/31046_20150701_170921.pdf

International Energy Agency. 2018. Market report: renewables 2018. Paris: IEA.

International Energy Agency. 2019. Renewables 2019. Paris: IEA.

International Hydropower Association. 2019. 2018 Hydropower status report. London: International Hydropower Association.

Jackson, M. 2017. Introduction: a critical bridging exercise. In Jackson, M. (ed). Coloniality, ontology, and the question of the posthuman. London: Routledge.

Joronen, M. and J. Häkli. 2017. Politicizing ontology. Progress in Human Geography 41(5): 561-579.

Juárez, I. 2016. Chepete y El Bala, el nuevo conflicto con los indígenas. Pagina Siete, December 21. [accessed May 28 2020]. https://www.paginasiete.bo/especial01/2016/12/21/chepete-bala-nuevo-conflictoindigenas-120867.html 
Kaup, B.Z. 2009. A neoliberal nationalization? People, politics, and power in Bolivia's natural gas sector. Latin American Perspectives 37(3): 123-138.

Lane, T. 2015. Sustainable Development Goals: how does hydropower fit in? International Hydropower Association, 1 October. [accessed: May 28, 2020]. https://www.hydropower.org/blog/sustainabledevelopment-goals-how-does-hydropower-fit-in

Larkin, B. 2013. The politics and poetics of infrastructure. Annual Review of Anthropology Annual Reviews 42(1): 327-343.

Lawhon, M. and J.T. Murphy. 2011. Socio-technical regimes and sustainability transitions: insights from political ecology. Progress in Human Geography 36(3): 354-378.

Leach M and I. Scoones. (eds.) 2010. Dynamic sustainabilities: technology, environment, social justice. London: Earthscan.

Leal, M. 2016. Belo Monte power lines will clear extensive vegetation. Diálogo Chino, September 8. [accessed May 28 2020] https://dialogochino.net/7240-belo-monte-power-lines-will-clear-extensive-vegetation/

Lees. A.C., C.A. Peres, P.M. Fearnside, M. Schneider and J.A.S. Zuanon. 2016. Hydropower and the future of Amazonian biodiversity. Biodiversity and Conservation 25(3)451-466.

Lefebvre, H. 1991[1974]. The production of space. Oxford: Blackwell.

Madeiro, C. 2017. Após Belo Monte, Altamira (PA) supera taxa de homicídios de país mais violento do mundo. IHU-Unisinos, 6th March. [accessed: May 28 2020]. http://www.ihu.unisinos.br/186-noticias/noticias2017/565448-apos-belo-monte-altamira-pa-supera-taxa-de-homicidios-de-pais-mais-violento-domundo

Mamani, P. 2011. Cartographies of indigenous power: identity and territoritality in Bolivia. In Fabricant, N. and B. Gustafson (eds.) Remapping Bolivia: resources, territory and indigeneity in a Pluri-National State. Santa Fe: School for Advanced Research.

Manorom, K. I.G. Baird, and B. Shoemaker. 2017. The World Bank, hydropower-based poverty alleviation and indigenous peoples: on-the-ground realities in the Xe Bang Fai river basin of Laos. Forum for Development Studies 44(2): 275-300.

Martínez, V. and O.L. Castillo. 2016. The political ecology of hydropower: social justice and conflict in Colombian hydroelectricity development. Energy Research and Social Science 22: 69-78.

McCarthy, J. 2015. A socio-ecological fix to capitalist crisis and climate change: the possibilities and limits of renewable energy. Environment and Planning A 47: 2845-2502.

McCully, P. 1996. Silenced rivers: the ecology and politics of large dams. London: Zed.

Merme, V.; R. Ahlers; and J. Gupta, 2014. Private equity, public affair: Hydropower financing in the Mekong Basin. Global Environmental Change 24: 20-29.

Middleton, C. 2009. Thailand's commercial bank's role in financing dams in Laos and the case for sustainable banking. International Rivers, December 1 [accessed May 28 2020]. https://www.internationalrivers.org/resources/thailand\%E2\%80\%99s-commercial-banks\%E2\%80\%99role-in-financing-dams-in-laos-and-the-case-for-sustainable

Mignolo, W.D. and C.E. Walsh. 2018. On decoloniality: concepts, analytics, praxis. Durham: Duke University Press.

Ministério Público Federal Procuradoria da República no Pará [MPF/PA]. 2017. Pesquisadores que estudam impactos da mineradora Belo Sun denunciam intimidação. MPF/PA, November 30. [accessed May 28 2020]. http://www.mpf.mp.br/pa/sala-de-imprensa/noticias-pa/pesquisadores-que-estudam-impactosda-mineradora-belo-sun-denunciam-intimidacao

Miranda, J.Q. de M. and J.A. Herrera. 2016. Altamira-PA: novos papéis de centralidade e reestruturação urbana a partir da instalação da UHE Belo Monte. Confins 28.

Movimentos dos Atingidos por Barragens [MAB]. 2013. MAB denuncia exploração sexual em áreas de barragens. Movimento dos Atingidos por Barragens, 20 March. [accessed May 28 2020]. http://www.mabnacional.org.br/noticia/mab-denuncia-explora-sexual-em-reas-barragens 
Movimento dos Atingidos por Barragens. 2015. People affected protest against the mining company Belo Sun. MAB, December 4. [accessed May 28 2020]. http://www.mabnacional.org.br/english/people-affectedprotest-against-mining-company-belo-sun

Nathan Green, W. and I.G. Baird. 2016. Capitalizing on compensation: hydropower resettlement and the commodification and decommodification of nature-society relations in Southern Laos. Annals of the American Association of Geographers 106(4): 853-873.

Neumann, R.P. 2006. Making political ecology. London: Hodder.

Neumann, R.P. 2010. Political ecology II: theorizing region. Progress in Human Geography 34(3): 368-374

Newell, P. and D. Mulvaney. 2013. The political economy of the 'just transition.' The Geographical Journal 179(2): 132-140

Peet, R. and M.J. Watts (eds.). 2004. Liberation ecologies: environment, development and social movements. London: Routledge.

Pellegrini, L. 2018. Imaginaries of development through extraction: the 'history of Bolivian petroleum' and the present view of the future. Geoforum 90: 130-141

Perreault, T. 2008. Natural gas, indigenous mobilization and the Bolivian state. Geneva: United Nations Research Institute for Social Development.

Perreault, T. 2013. Nature and nation: hydrocarbons, governance, and the territorial logics of "resource nationalism" in Bolivia. In Bebbington, A.J. and J. Bury (eds.). Subterranean struggles: new dynamics of mining, oil, and gas in Latin America. Austin, TX.: University of Texas Press.

Perreault, T. and G. Valdivia. 2010. Hydrocarbons, popular protest and national imaginaries: Ecuador and Bolivia in comparative context. Geoforum 41(5): 689-699.

Poirier, C. 2017. Toxic mega-mine looms Over Belo Monte's affected communities. Amazon Watch, April 4. [accessed May 28 2020]. https://amazonwatch.org/news/2017/0404-toxic-mega-mine-looms-over-belomontes-affected-communities

Radcliffe, S. 2012. Development for a postneoliberal era? Sumak kawsay, living well and the limits to decolonisation in Ecuador. Geoforum 43(2): 240-249.

Radhuber I.M., M. Chávez León and D. Andreucci. 2021. Expansión extractivista, resistencia comunitaria y 'despojo político' en Bolivia. Journal of Political Ecology 28: 205-223.

La Razón Digital. 2016. ENDE: Bolivia generará 11.000 MW de energía por medio de hidroeléctricas hasta 2025. La Razón Digital, October 20. [accessed May 28 2020]. https://web.archive.org/web/20191121124551/http://www.la-razon.com:80/economia/ENDE-Boliviagenerara-MW-hidroelectricas_0_2585741478.html

Robbins, P. 2011. Political ecology: a critical introduction. London: Wiley.

Rutherford, J. and O. Coutard. 2014. Urban energy transitions: places, processes and politics of socio-technical change. Urban Studies 51(7): 1353-1377.

Schulz, C. and W.M. Adams. 2019. Debating dams: The World Commission on Dams 20 years on. Wiley Interdisciplinary Reviews: Water 6(5).

Scudder, T. 2005. The future of large dams. Abingdon: Routledge.

Sikor, T. and R. Norgaard. 1999. Principles for sustainability: protection, investment, cooperation and innovation. In Kohn, J., J.M. Gowdy, F. Hinterberger and J. Van der Straaten (eds.). Sustainability in question: the search for a conceptual framework. Cheltenham: Edward Elgar.

Smith, N. 1984. Uneven development: nature, capital and the production of space. London: Verso.

Smith N. 1986. On the necessity of uneven development. International Journal of Urban and Regional Research 10(1): 87-104.

Smith, N. 2007. Nature as accumulation strategy. Socialist Register 43: 16-36.

Soito, J.L.D.S. and M.A.V. Freitas. 2011. Amazon and the expansion of hydropower in Brazil: Vulnerability, impacts and possibilities for adaptation to global climate change. Renewable and Sustainable Energy Reviews 15(6): 3165-3177. 
Southgate, T. (ed.) 2016. Belo Monte: after the flood. (Film). USA: International Rivers and Amazon Watch.

Sullivan, Z. 2017. Unexamined synergies: dam building and mining go together in the Amazon. Mongabay, June 22. [accessed May 28 2020] https://news.mongabay.com/2017/06/unexamined-synergies-dambuilding-and-mining-go-together-in-the-amazon/

Svampa, M. 2015. Commodities consensus: neoextractivism and enclosure of the commons in Latin America. South Atlantic Quarterly 114(1): 65-82.

Swyngedouw, E. 2010. Apocalypse forever? Theory, Culture and Society 27(2-3): 213-232.

Sundberg, J., 2014. Decolonizing posthumanist geographies. Cultural Geographies 21(1): 33-47.

Talento, A. 2014. Operarios de Belo Monte pagam sexo com vale alimentacao. Folha de S.Paulo, 14 June. [accessed: May 28 2020]. https://www1.folha.uol.com.br/cotidiano/2014/06/1469550-operarios-debelo-monte-pagam-sexo-com-vale-alimentacao.shtml

Teixeira, M. and L. Costa. 2015. UPDATE 1-China's State Grid to build Brazil's longest power line. Reuters, July 17. [accessed May 28 2020] https://www.reuters.com/article/brazil-power-auction/update-1-chinasstate-grid-to-build-brazils-longest-power-line-idUSL2N0ZX0P420150717

Tuck, E. and K.W. Yang. 2012. Decolonization is not a metaphor. Decolonization: Indigeneity, Education and Society 1(1).

Turhana, E. and A.C. Gündoğan. 2018. The post-politics of the green economy in Turkey: re-claiming the future? Journal of Political Ecology 24(1): 277.

United Nations Framework Convention on Climate Change. 2018. How hydropower can help climate action. United Nations Framework Convention on Climate Change, 21 November [accessed: May 28, 2020]. https://unfccc.int/news/how-hydropower-can-help-climate-action

USAID. 2008. Bolivia tropical forestry and biodiversity assessment. Washington, DC: USAID.

Walsh, C. 2010. Development as Buen Vivir: institutional arrangements and (de)colonial entanglements. Development 53(1): 15-21.

Walsh, C. 2011. Afro and indigenous life-visions in/and politics: (de)colonial perspectives in Bolivia and Ecuador. Bolivian Studies Journal 18: 49-69.

Watts, M.J. 2010. Resource curse? governmentality, oil and power in the Niger Delta, Nigeria. Geopolitics 9(1): 50-80.

Wilson, J. and E. Swyngedouw (eds.). 2014. The post-political and its discontents: spaces of depoliticization, spectres of radical politics. Edinburgh: Edinburgh University Press.

World Bank. 2009. Directions in hydropower: scaling up for development. Washington, D.C.: World Bank.

World Commission on Dams. 2000. Dams and development: a new framework for decision-making. London: Earthscan.

World Energy Council. 2015. Charting the upsurge in hydropower development. London: World Energy Council.

Movimento Xingu Vivo para Sempre. 2010. Letter to Secretary of Development, Science and Technology of the State of Pará. Translated by Survival International. [accessed May 28 2020]. http://assets.survivalinternational.org/documents/406/SEDEC_letter_English.pdf

Zhouri, A. 2010. "Adverse forces" in the Brazilian Amazon: developmentalism versus environmentalism and indigenous rights. The Journal of Environment and Development 19(3): 252-273.

Zimmerer, K.S. 2015. Environmental governance through "speaking like an indigenous state" and respatializing resources: ethical livelihood concepts in Bolivia as versatility or verisimilitude? Geoforum 64: 314-324. 